\title{
PERSEPSI MAHASISWA HUBUNGAN INTERNASIONAL UNIVERSITAS FAJAR TERHADAP FILM "NO" KARYA PABLO LARRAÍN
}

\author{
Achmad Zulfikar ${ }^{1}$ \\ Dosen Pengampu Mata Kuliah Komunikasi Politik Internasional \\ Program Studi Ilmu Hubungan Internasional \\ Universitas Fajar
}

\begin{abstract}
Abstrak
Publikasi ini bertujuan untuk mengekspos persepsi mahasiswa terhadap suatu fenomena melalui analisis film. Film "No" dipilih dengan pertimbangan bahwa unsur-unsur yang terdapat dalam film merefleksikan proses komunikasi politik yang terjadi di suatu negara. Metode yang digunakan dalam mempersiapkan mahasiswa melakukan analisis film yakni sebelum pemutaran film, mahasiswa diberikan penjelasan singkat mengenai tiga tahapan sebelum menganalisis film diantaranya: menonton film, menguraikan film dan menggabungkan hasil analisis. Dari proses ini diketahui persepsi mahasiswa Hubungan Internasional Universitas Fajar terhadap film "No" karya Pablo Larrain dikategorisasi menjadi alur cerita dan aspek komunikasi politik dalam film. Jika dikaitkan dengan tuujuan publikasi ini, maka penugasan analisis film "No" telah menunjukkan persepsi yang diharapkan yakni diperolehnya pesan bahwa dari film ini ditunjukkan bagaimana proses komunikasi politik melalui strategi periklanan. Publikasi ini dapat dikembangkan lebih lanjut dengan variasi film yang lebih beragam menyesuaikan dengan tujuan pembelajaran yang hendak dicapai dan perlunya pengembangan metode analisis film yang lebih terstruktur dan sesuai dengan kebutuhan mahasiswa.
\end{abstract}

Kata Kunci: Persepsi Mahasiswa, Analisis Film, Strategi Periklanan

\begin{abstract}
This publication aims to expose students' perceptions of a phenomenon through film analysis. The film "No" was chosen with the consideration that the elements contained in the film reflect the process of political communication that occurs in a country. The method used in preparing students to conduct film analysis is before the film screening, students are given a brief explanation of the three stages before analyzing the film including: watching a film, describing a film and combining the results of the analysis. From this process, it is known that the perception of the students of International Relations at Universitas Fajar towards the film "No" by Pablo Larrain is categorized into the storyline and aspects of political communication in the film. The assignment of the analysis of the film "No" has shown the expected perception, namely the message that this film shows how the process of political communication through advertising strategies. This publication can be further developed with a variety of films that are more diverse adjusting to the learning objectives to be achieved and the need to develop a film analysis method that is more structured and in accordance with the students needs.
\end{abstract}

Keywords: Students Perception, Film Analysis, Advertising Strategy

1 (D) https:// orcid.org/ 0000-0003-2215-5778. Surel korespondensi: apa@kabarfikar.com 


\section{PENDAHULUAN}

Persepsi mahasiswa ini dikompilasi dari penugasan Analisis Film yang diberikan kepada mahasiswa Hubungan Internasional Universitas Fajar pada mata kuliah Komunikasi Politik Internasional. "No" dipilih sebagai film yang dianalisis oleh mahasiswa dengan pertimbangan bahwa unsur-unsur yang terdapat dalam film merefleksikan proses komunikasi politik yang terjadi di suatu negara. Sehingga, film ini dianggap mendukung proses pembelajaran untuk memberikan pemahaman kepada mahasiswa terkait proses terjadinya komunikasi politik internasional. Publikasi ini bertujuan untuk mengekspos persepsi mahasiswa terhadap suatu fenomena melalui analisis film. Diharapkan tugas yang dihasilkan dapat diakses secara luas dan memberikan masukan konstruktif bagi pengembangan kapasitas mahasiswa dan proses pembelajaran.

\section{METODE}

Persepsi mahasiswa didapatkan dari hasil analisis film yang dilakukan oleh mahasiswa. Adapun metode yang digunakan dalam mempersiapkan mahasiswa melakukan analisis film yakni sebelum pemutaran film, terlebih dahulu dosen pengampu memberikan penjelasan singkat mengenai teknik analisis film. Dalam hal ini, penulis sekaligus dosen pengampu mengadopsi penjelasan dari Wikihow.com tentang Menganalisis Film. Dalam powerpoint yang ditampilkan kepada mahasiswa, dosen pengampu menitikberatkan pada tiga penjelasan utama yakni menonton film, menguraikan film dan menggabungkan hasil analisis. Penulis akan menguraikan secara singkat menjelaskan ketiga poin tersebut.

Pertama menonton film. Jika Anda belum pernah menonton film yang ingin dianalisis, tidak perlu melakukan riset secara mendalam terlebih dahulu. Akan lebih baik, jika Anda menonton fil tersebut dan membiarkannya menimbulkan kesan dalam diri Anda, bukan sebaliknya. Anda harus berkonsentrasi penuh pada film agar bisa menulis analisis yang bagus sesudahnya. Buatlah beberapa catatan. Anda bisa menulis beberapa hasil pengamatan sementara film berjalan. Namun, Anda harus berkonsentrasi pada film, bukan pada catatan. Beberapa hal yang dapat dicatat, diantaranya poin penting dari plot, dialog krusial atau sering diulang dan adegan yang sangat luar biasa. 
Catatlah semua hal yang membuat Anda terkesan atau menurut Anda penting di akhir film.

Kedua, menguraikan film. Langkah pertama yakni selidiki latar belakang film. Mengetahui informasi tentang bagaimana film yang ingin dianalisis dibuat akan memberi banyak pemahaman mengenai film tersebut. Langkah kedua pikirkan tentang busur cerita (story arc). Jika Anda ingin mengetahui apakah film memiliki plot yang bagus, tuliskan peristiwa-peristiwa penting yang Anda ingat. Jika Anda bisa mengingatnya secara berurutan, itu pertanda baik. Langkah ketiga, libatkan diri dalam tulisan. Cobalah mencari tahu apakah Anda memiliki semua informasi yang dibutuhkan dari penulisan film. Apakah menurut Anda dialog dalam film terdengar seperti percakapan di kehidupan nyata. Identifikasi lelucon di dalam film dan tentukan apakah berhasil disampaikan dengan baik. Ketiga langkah ini membantu Anda untuk menguraikan film dan mempersiapkan diri Anda untuk membuat analisis film.

Ketiga, menggabungkan hasil analisis. Dalam hal ini, Anda harus mengumpulkan fakta-fakta yang mendukung konsep Anda tentang tema film, yang bisa berupa konsep, warna, atau bahkan gambar atau dialog yang diulang-ulang sepanjang film. Telaah pemikiran Anda untuk mencari berbagai elemen film dan lihatlah apakah Anda bisa mendapatkan dukungan untuk pemikiran tersebut. Tulisan terbaik harus dilandasi antusiasme. Jadi salurkan apa yang membuat Anda bersemangat. Selanjutnya, mulailah dengan pengantar. Sebutkan latar belakang film, termasuk orang-orang yang terlibat dalam proses pembuatannya dan tuliskan ekspektasi apa yang Anda miliki. Lalu, rangkumlah plot. Buatlah satu atau tiga kalimat untuk menjelaskan persiapan plot dan inti dari konflik utama. Buatlah rangkuman sesingkat mungkin. Kemudian, jelajahi tema yang Anda anggap menarik. Ajukan hipotesis tentang apa yang menurut Anda ingin disampaikan oleh pembuat film atau bahkan apa yang sebenarnya mereka harapkan akan muncul di pikiran Anda. Terakhir, kritiklah aspek film yang Anda tidak sukai. 


\section{HASIL DAN PEMBAHASAN}

\section{Sinopsis Film "No"}

Gambar 1. Poster Film "No"

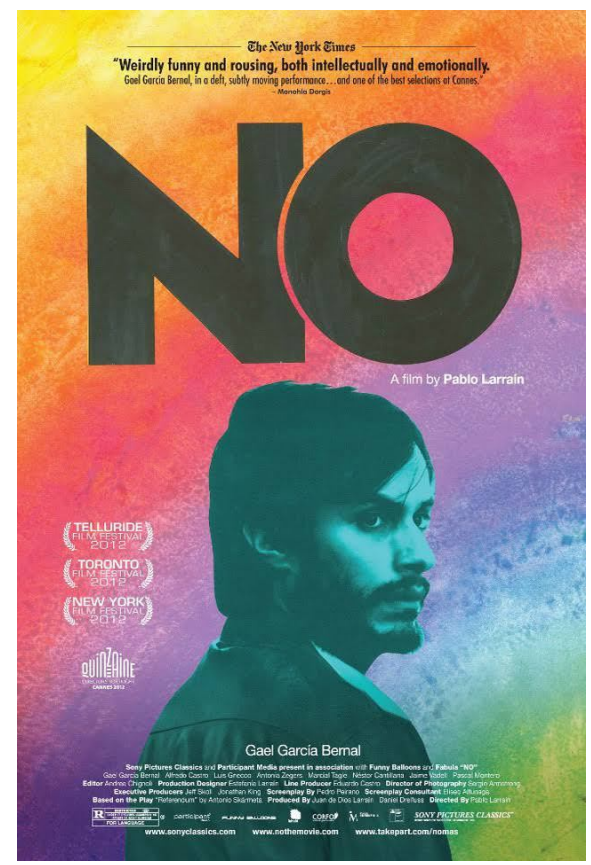

Sumber: Wikipedia

"No" adalah sebuah film drama tahun 2012 yang disutradarai oleh Pablo Larraín. Film ini mengangkat cerita naskah El Plebiscito karya Antonio Skármeta. Aktor Meksiko Gael García Bernal berperan sebagai tokoh utama bernama René, seorang ahli periklanan yang hidup di Cile pada zaman 1980-an. Latar historis yang diulas dalam film ini adalah ketika strategi periklanan mulai digunakan secara luas di kampanya politik. Kisah kampanye dalam cerita film ini merupakan bagian dari referendum tahun 1988 yang bersejarah yang menentukan apakah pemimpin diktator Augusto Pinochet tetap menjadi pemimpin untuk delapan tahun berikutnya.

\section{Persepsi Mahasiswa Hubungan Internasional Universitas Fajar terhadap Film "No"}

Persepsi mahasiswa ini didapatkan dari hasil analisis film "No" (Lampiran 1) yang dikerjaskan oleh 15 orang mahasiswa, kemudian setelah ditelaah lebih lanjut oleh dosen pengampu, maka dipilih 6 orang mahasiswa yang memiliki originalitas dan keruntutan dalam menganalisis film. Mereka berasal dari berbagai latar belakang, 
sehingga hasil persepsi terhadap film ini merefleksikan pemahaman mereka dan juga dipengaruhi latar belakang yang dimiliki. Hasil analisis film tersebut kemudian dipetakan dipetakan bagaimana persepsi mahasiswa tersebut secara umum berdasarkan hasil analisis yang telah dilakukan.

Tabel 1. Persepsi Mahasiswa terhadap Film "No"

\begin{tabular}{|c|l|c|l|}
\hline No. & \multicolumn{1}{|c|}{ Nama Mahasiswa } & Kode & \multicolumn{1}{|c|}{ Gambaran Persepsi } \\
\hline 1. & $\begin{array}{l}\text { Evelyn Gabriella } \\
\text { Limbongan }\end{array}$ & M1 & $\begin{array}{l}\text { - Strategi periklanan untuk kampanye politik di } \\
\text { Chile; } \\
\text { - Dua kubu yang bersaing menarik perhatian } \\
\text { masyarakat. }\end{array}$ \\
\hline 2. & Claudia Rante Arung & M2 & - Kontestasi kampanye "Ya" dan "Tidak" \\
\hline 3. & $\begin{array}{l}\text { Dessire Michelle } \\
\text { Ardhea Tinungki }\end{array}$ & M3 & $\begin{array}{l}\text { - Komunikasi melalui iklan berperan penting } \\
\text { sebagai penentu nasib negara; } \\
\text { - Komunikasi melalui iklan menarik perhatian } \\
\text { dan mempengaruhi masyarakat. }\end{array}$ \\
\hline 5. & Yitri & M4 & $\begin{array}{l}\text { - Mengurai latar belakang konflik di Chile } \\
\text { dalam perebutan kekuasaan; }\end{array}$ \\
\hline 6. & Noviyanti Azis & M5 & $\begin{array}{l}\text { - Menguraikan iklan yang ditampilkan kubu } \\
\text { "Yes" dan "No; } \\
\text { - Menguraikan visualisasi yang dilakukan } \\
\text { dalam film. }\end{array}$ \\
\hline
\end{tabular}

Tabel di atas menggambarkan persepsi mahasiswa yang diuraikan melalui analisis film. Penulis secara umum menarik tema besar yang dibahas dalam analisis film tersebut. Jika dilihat persepsi M1-M6 di atas, berfokus pada konflik yang diceritakan dalam film akibat kepemimpinan Agusto Pinochet, kontestasi kampanye "Yes" dan "No" hingga bagaimana komunikasi politik melalui periklanan mempengaruhi masyarakat. Sehingga, persepsi ini dapat dikategorikan menjadi dua yakni Alur Cerita dan Aspek Komunikasi Politik dalam Film.

\section{Alur Cerita}

Sebagian besar mahasiswa mempersepsikan alur cerita berfokus pada konflik yang diakibatkan kepemimpinan Agusto Pinochet yang ingin melanggengkan 
kekuasaannya melalui pemilihan dan kontestasi dua kubu "Ya" dan "Tidak". Seperti yang dianalisis sebagai berikut:

"Ada 2 kubu yang saling bersaing menarik perhatian masyarakat mereka menamakan kubu tersebut "NO" dan "YES". Kubu "NO" mayoritas masyarakat seni Chile, terbukti efektif dengan serangkaian presentasi menghibur dan mendalam yang memiliki daya tarik lintas-demografi tak tertahankan. Sedangkan dari kubu "YES", memiliki data ekonomi yang kering dan positif dalam mendukung dan beberapa personil kreatif panggilan, yang diejek bahkan oleh pejabat pemerintah sebagai oknum politik yang kasar dan berat tangan" (M1)

"Di dalam kampanye bersejarah berlangsung tersebut, terdapat dua kubu yaitu kampanye YA dan TIDAK. Kampanye TIDAK dibuat oleh mayoritas komunitas artistic Chili yang terbukti efektif dengan sebuah serangkaian presentasi yang menghibur serta berwawasan luas yang memiliki daya tarik lintas demografi yang tak tertahankan" (M2)

"Kubu "NO" melakukan kampanye yang berlangsung selama 27 malam melalui iklan televisi di mana masing-masing pihak memiliki 15 menit per malam untuk menyajikan titik pandang mereka dan selama bulan itu, kampanye yang diciptakan oleh mayoritas masyarakat seni Chile terbukti efektif dengan serangkaian presentasi menghibur dan mendalam yang memiliki daya tarik. Sebaliknya, iklan kampanye kubu "YES" memiliki data ekonomi yang kering dan positif dalam mendukung dan beberapa personil kreatif panggilan yang diejek bahkan oleh pejabat pemerintah sebagai oknum politik yang kasar dan berat tangan" (M4)

"Kampanye Yes sama-sama digambarkan sebagai orang yang sibuk mendiskusikan gambar dan, kemudian di film, bagaimana merusak pesan oposisi melalui ejekan daripada kritik aktual. Pada satu titik, kubu pro-Pinochet bahkan mendiskusikan keinginan mereka untuk memiliki anggota kunci dari kampanye No yang dibuat untuk menghilang, tetapi tidak dapat melakukannya karena itu akan menjadi pandangan buruk mengingat semua pengawasan internasional yang dialami Chili" (M5)

"Latar belakang tersebut membuat terbentuknya referendum yang menawarkan dua kubu yaitu "NO" dan "SI". "SI" atau Yes menyatakan Agusto Pinochet dan kekuasaan militernya melanjutkan pemerintahan hingga 8 tahun lagi tentunya di prakarsai oleh tim Agusto Pinochet sedang "NO" menyatakan penolakan terhadap segala bentuk pemerintahan Agusto Pinochet dan memberikan waktu setahun untuk menyelesaikan masa pemerintahannya, Tim ini di prakarsai oleh Aktivis" (M6)

Persepsi oleh kelima subjek di atas menunjukkan kontestasi kubu "Ya" dan "Tidak". Seperti subjek M1, M2 dan M4 menganalisis bahwa Kubu "Tidak" melakukan 
serangkaian presentasi menghibur dan mendalam yang memiliki daya tarik lintasdemografi, sedangkan kubu "Yes" memiliki data ekonomi yang kering dan dalam mendukung kampanye kelompoknya. Selanjutnya, subjek M5 menggambarkan kubu kampanye "Yes" memiliki keinginan untuk menghalangi kampanye kubu "No" tetapi urung dilakukan. Kemudian, subjek M6 menyorot kubu "No" yang dengan pernyataan keras menolak upaya Agusto Pinochet melanggengkan kekuasaan.

Selain kontestasi dalam film ini juga dianalisis konflik yang terjadi di Chile yang merupakan latar terjadinya kontestasi "Ya" dan "Tidak". Sebagaimana dianalisis sebagai berikut:

"Film ini bercerita tentang keadaan negara Cile lima belas tahun setelah penguasa militer yang diktator menghadapi tekanan internasional. Publik negara itu diminta oleh pemerintahannya untuk melakukan pemilihan umum secara nasional untuk memilih jenderal Augusto Pinochet agar kembali menjadi pemimpin negara tersebut selama delapan tahun berikutnya atau mereka harus membuka sebuah pemilihan demokratis pada tahun berikutnya" (M3)

Persepsi oleh subjek M3 di atas memberikan gambaran bahwa konflik di Chile disebabkan penguasa militer yang dictator menghadapi tekanan internasional, sehingga kontestasi "Ya" dan "Tidak" melibatkan petahana Agusto Pinochet di kubu "Ya/Yes/Si" dan kubu revolusioner yang menginginkan perubahan di Chile di kubu "Tidak/No".

\section{Aspek Komunikasi Politik dalam Film}

Komunikasi politik merupakan aspek yang dipertimbangkan hadir dan berkesan dari pemutaran film "No" ini. Hal yang menarik, setiap mahasiswa menangkap pesan yang berbeda terkait aspek komunikasi politik dalam film ini. Beberapa diantaranya sebagai berikut:

"Film ini memberikan gambaran kepada saya mengenai strategi periklanan mulai digunakan secara luas untuk kampanye politik negara Chili" (M1)

"Di dalam film ini terdapat historis taktik iklan dalam kampanye politik.,,," (M2)

"Film ini memperlihatkan bagaimana komunikasi dalam hal ini media periklanan benar-benar berperan penting atau dapat dikatakan pula sebagai penentu nasib negara Chile, apakah akan Tetap dipimpin oleh rezim yang 
diktator selama 8 tahun kedepannya atau dapat membawa kebebasan bagi negara Chile" (M3)

“... Film ini menyederhanakan sejarah dan terutama fokus utamanya adalah pada kampanye iklan televisi..." (M4)

"Nilai yang terlihat menyakinkan para penonton bahwa media digital akan sangat mempengaruhi pengambilan keputusan negara dan internasional di masa ini dan masa depan ..." (M6)

Persepsi terhadap aspek komunikasi politik dalam film tersebut tergambar dari subjek M1, M2, M3, M4 dan M6. Subjek M1, M2, M3 dan M4 menyorot strategi periklanan ditunjukkan dalam film. Sedangkan, subjek M6 lebih menyorot pada perkembangan media dalam mempengaruhi pengambilan keputusan negara.

\section{PENUTUP}

\section{Kesimpulan}

Berdasarkan penjelasan di atas, maka diketahui persepsi mahasiswa Hubungan Internasional Universitas Fajar terhadap film "No" karya Pablo Larraín dikategorisasi menjadi alur cerita dan aspek komunikasi politik dalam film.

Kategori alur cerita menyoroti dua hal utama dari film yakni kontestasi kubu "Ya/Yes/Si" dan "Tidak/No" dan konflik di Chile. Sedangkan, kategori aspek komunikasi politik dalam film menemukan persepsi yang sama terhadap penggambaran strategi periklanan dan perkembangan media dalam pengambilan keputusan.

Jika dikaitkan dengan tujuan dari publikasi ini, maka penugasan analisis film "No" yang diberikan kepada mahasiswa telah menunjukkan persepsi yang diharapkan yakni dengan diperolehnya pesan bahwa dalam film ini ditunjukkan bagaimana proses komunikasi politik melalui strategi periklanan.

\section{Saran}

Publikasi ini dapat dikembangkan lebih lanjut dengan variasi film yang lebih beragam menyesuaikan dengan tujuan pembelajaran yang hendak dicapai. Di samping itu, perlu dikembangkan metode analisis film yang lebih terstruktur dan sesuai dengan kebutuhan mahasiswa. 


\section{PENGHARGAAN}

Penulis sekaligus dosen pengampu mengucapkan terima kasih kepada seluruh mahasiswa yang terlibat dalam perkuliahan Komunikasi Politik Internasional dan juga kepada Program Studi Ilmu Hubungan Internasional Universitas Fajar yang telah mempercayakan kepada penulis sebagai pengampu mata kuliah ini. Semoga publikasi sederhana ini menjadi awal yang baik bagi mahasiswa untuk lebih mengembangkan daya kritis dan kapasitas akademiknya.

\section{REFERENCES}

Menganalisis Film, diakses dari https://id.wikihow.com/Menganalisis-Film pada 4 November 2018

No (Film tahun 2012), diakses dari https://id.wikipedia.org/wiki/No_(film_tahun_2012) pada 4 November 2018. 


\section{LAMPIRAN 1}

\section{Hasil Analisis Film "No" dari Mahasiswa Hubungan Internasional Universitas Fajar}

\section{Evelyn Gabriella Limbongan (M1)}

Film ini memberikan gambaran kepada saya mengenai strategi periklanan mulai digunakan secara luas untuk kampanye politik negara Chili. Publik negara itu diminta oleh pemerintahannya untuk melakukan pemilihan umum secara nasional. Kampanye yang dimaksud ialah melalui iklan berlangsung selama 27 malam di stasiun televisi, masing-masing pihak memiliki 15 menit per malam untuk menyajikan titik pandang mereka.

Ada 2 kubu yang saling bersaing menarik perhatian masyarakat mereka menamakan kubu tersebut "NO" dan "YES". Kubu "NO" mayoritas masyarakat seni chile, terbukti efektif dengan serangkaian presentasi menghibur dan mendalam yang memiliki daya tarik lintas-demografi tak tertahankan. Sedangkan dari kubu "YES", memiliki data ekonomi yang kering dan positif dalam mendukung dan beberapa personil kreatif panggilan, yang diejek bahkan oleh pejabat pemerintah sebagai oknum politik yang kasar dan berat tangan.

Beberapa pihak menilai, termasuk Genaro Arriagada, yang menjadi pengarah kampanye "No" yang nyata, menyebutkan bahwa film ini menyederhanakan sejarah dan terutama berfokus utama pada kampanye iklan televisi, tidak menghiraukan peran penting usaha pendaftaran pemilik hak suara yang berperan dalam menaikkan suara "No".

\section{Claudia Rante Arung (M2)}

Di dalam film ini terdapat historis taktik iklan dalam kampanye politik. Dan setelah kediktatoran militer selama lima belas tahun dan menghadapi tekanan internasional yang cukup besar akhirnya pemerintah Chili memilih suara Plesebit Nasional mengenai apakah Augusto Pinochet tetap berkuasa atau apakah ada pemilihan presiden yang demokratis dan terbuka.

Alih-alih muncul lagi seorang pencipta iklan yang sukses Rene Saavedra yang sedang berkonsultasi dengan suatu organisasi yang telah diajukan. Dan dia setuju untuk berpartisipasi dan mendapati bahwa iklan tersebut adalah sebuah pelanggaran rezim 
yang tidak mampu yang dibuat oleh sebuah organisasi yang tidak memiliki kepercayaan dalam upayanya.

Mereka kemudian mengambil pendekatan promosi yang ringan yang menekankan konsep abstrak untuk menantang kekhawatiran bahwa pemungutan suara dalam referendum berada dibawah junta militer yang brutal. Sebagai pemberhentian yang mudah dari pelanggaran rezim yang mengerikan, proposal disetujui untuk kampanye.

Di dalam kampanye bersejarah berlangsung tersebut, terdapat dua kubu yaitu kampanye YA dan TIDAK. Kampanye TIDAK dibuat oleh mayoritas komunitas artistic Chili yang terbukti efektif dengan sebuah serangkaian presentasi yang menghibur serta berwawasan luas yang memiliki daya tarik lintas demografi yang tak tertahankan.

Sebaliknya dengan komunitas YA, mereka hanya mengeringkan data ekonomi positif demi kebaikan dan beberapa personel kreatif. Dan pada saat hari referendum saat ini tampak bahwa komunitas YA lebih unggul, namun hasil akhirnya ternyata lebih tegas di pihak komunitas TIDAK. Bukti terakhir bahwa hanya datang saat pasukan yang mengeluarkan narkkas, seperti kabar perintah militer Chili yang memaksa untuk mengakui tersebut. Setelah sukses mereka melanjutkan bisnis periklanan normal mereka dengan seorang presiden yang baru mereka. Dan di film terakhir ini juga menceritakan bahwa semua kekuasaan dan kekuatan diserahkan kepada Presiden yang baru terpilih

\section{Dessire Michelle Ardhea Tinungki (M3)}

Film ini bercerita tentang keadaan negara Cile lima belas tahun setelah penguasa militer yang diktator menghadapi tekanan internasional. Publik negara itu diminta oleh pemerintahannya untuk melakukan pemilihan umum secara nasional untuk memilih jenderal Augusto Pinochet agar kembali menjadi pemimpin negara tersebut selama delapan tahun berikutnya atau mereka harus membuka sebuah pemilihan demokratis pada tahun berikutnya.

Film ini memperlihatkan bagaimana komunikasi dalam hal ini media periklanan benar-benar berperan penting atau dapat dikatakan pula sebagai penentu nasib negara Chile, apakah akan Tetap dipimpin oleh rezim yang diktator selama 8 tahunkedepannya atau dapat membawa kebebasan bagi negara Chile. Juga terlihat bagaimana kampanye dalam bentuk iklan ini benar-benar telah masuk tahap yang bebas, dimana dua kubu 
saling menyerang secara langsung dengan bentuk komunikasi iklan yang lebih dapat menarik perhatian masyarakat sekaligus mempengaruhi masyarakat daripada bentuk kampanye lainnya. Sekali lagi memperlihatkan bahwa komunikasi dalam bentuk yang lebih kreatif lebih bekerja dan menarik perhatian masyarakat daripada komunikasi bentuk lainnya.

\section{Fitri (M4)}

Film "NO" menceritakan keadaan publik di negara Cile lima belas tahun setelah penguasa militer yang menghadapi tekanan internasional. Publik negara itu diminta oleh pemerintahannya untuk melakukan pemilihan umum secara nasional untuk memilih jenderal Augusto Pinochet agar kembali menjadi pemimpin negara tersebut atau melakukan pemilihan demokratis pada tahun berikutnya. Seorang pencipta iklan bernama Rene Savedra yang didekati oleh komite yang menamakan diri mereka komite "NO" untuk berkonsultasi pada iklan yang akan mereka gunakan dalam promosi komite mereka, iklan yang dimaksud adalah iklan yang tidak menarik pelanggaran rezim yang diciptakan oleh sebuah organisasi yang tidak memiliki keyakinan dalam upayanya meyakinkan publik. Meskipun Savedra, anaknya dan rekan-rekannya akhirnya diintimidasi oleh pihak berwenang dan sementara tema pemasaran ortodoks diberhentikan oleh beberapa orang, itu merupakan buah dari adanya anggota yang melakukan pemberhentian hal yang mereka anggap sebagai pelanggaran mengerikan terhadap rezim tersebut.

Kubu "NO" melakukan kampanye yang berlangsung selama 27 malam melalui iklan televisi di mana masing-masing pihak memiliki 15 menit per malam untuk menyajikan titik pandang mereka dan selama bulan itu, kampanye yang diciptakan oleh mayoritas masyarakat seni Chile terbukti efektif dengan serangkaian presentasi menghibur dan mendalam yang memiliki daya tarik. Sebaliknya, iklan kampanye kubu "YES" memiliki data ekonomi yang kering dan positif dalam mendukung dan beberapa personil kreatif panggilan yang diejek bahkan oleh pejabat pemerintah sebagai oknum politik yang kasar dan berat tangan.

Menurut saya, film ini dijadikan pengarah kampanye dari kubu "No" yang nyata. Film ini menyederhanakan sejarah dan terutama fokus utamanya adalah pada kampanye 
iklan televisi. Dalam film ini juga tidak menghiraukan peran penting usaha pendaftaran pemilik hak suara yang berperan dalam menaikkan suara kubu "No".

\section{Yenny Susanti (M5)}

Film ini didasarkan pada peristiwa nyata, tetapi menampilkan seorang periklanan fiktif bernama René Saavedra (Gael García Bernal) sebagai protagonisnya. Peserta dalam kampanye bertindak dalam film sebagai versi dari diri mereka sendiri, menyela dengan rekaman sebenarnya dari diri mereka sendiri ketika mereka awalnya muncul di berbagai tempat yang disiarkan televisi selama kampanye. Larraín telah menembak No dengan kamera video U-matic berkualitas rendah yang digunakan untuk siaran televisi di Chile sepanjang tahun 1980-an, semakin mengaburkan batasan antara rekaman arsip yang sebenarnya dan presentasi peristiwa nyata yang fiksi. Gabungan dari partisipan yang sebenarnya dalam rekaman arsip dengan adegan re-enacted yang dibintangi seorang aktor internasional terkenal dengan sengaja menciptakan kebingungan tentang apa yang nyata dan apa yang merupakan versi realitas yang terkonstruksi. Ini bukan kesadaran diri yang terang-terangan juga bukan teknik jarak karena film tetap terlibat di seluruh, tetapi itu berdiri sebagai titik perbedaan untuk film seperti Argo (Ben Affleck, 2012) di mana sejarah diubah menjadi film bergenre narasi Hollywood klasik atau Zero Dark Thirty (Kathryn Bigelow, 2012), yang mengadopsi gaya veneer faux-cinema untuk mewujudkan estetika realisme.

Yang menarik dari film ini menurut saya adalah terletak pada gaya visual film No sangat berhasil menginformasikan tema dan narasi film, yang menyangkut sejauh mana René mengkompromikan pentingnya gerakan anti-Pinochet untuk menghasilkan kampanye iklan yang sukses. Ketegangannya adalah antara keinginan untuk bertindak dengan jujur dan dengan integritas versus keinginan untuk melakukan apa pun untuk mengubah suara yang belum diputuskan menjadi Tidak ada suara. Para anggota kiri yang aktif dari kampanye Tidak ada yang ingin menggunakan airtime dialokasikan untuk akhirnya berbicara tentang ketidaksetaraan ekonomi yang mengerikan dan pelanggaran hak asasi manusia di bawah Pinochet, sementara René ingin menjual demokrasi seperti dia akan menjual produk konsumsi. Validitas pesan menyenangkan René versus pesan yang otentik dan terlibat secara politik sengaja dibiarkan ambigu di sepanjang film. Seperti yang dikatakan René, budaya ketakutan di Chili telah 
menghasilkan 'keputusasaan yang terpelajar' bahwa hanya pesan 'kebahagiaan yang akan datang' yang optimis dan ke depan yang dapat dengan serius diharapkan untuk diatasi. Namun, film ini juga secara sinis menggambarkan René sebagai seseorang yang membawa retorika dan antusiasme yang sama kepada setiap kliennya, terlepas apakah mempromosikan kebebasan demokratis atau Free Cola.

Kampanye Yes sama-sama digambarkan sebagai orang yang sibuk mendiskusikan gambar dan, kemudian di film, bagaimana merusak pesan oposisi melalui ejekan daripada kritik aktual. Pada satu titik, kubu pro-Pinochet bahkan mendiskusikan keinginan mereka untuk memiliki anggota kunci dari kampanye No yang dibuat untuk menghilang, tetapi tidak dapat melakukannya karena itu akan menjadi pandangan buruk mengingat semua pengawasan internasional yang dialami Chili. Kampanye Ya mengidentifikasi daya tarik kapitalisme Pinochet sebagai menjual kepercayaan pasar bebas bahwa siapa pun bisa menjadi kaya (sebagai lawan dari semua orang bisa menjadi kaya) dan semua orang berpikir mereka bisa menjadi siapa pun. Penentangan René dalam kampanye Ya adalah bos dan kolega Lucho Guzmán (Larraín regular Alfredo Castro) yang juga menginginkan kampanyenya berhasil dengan melakukan apa pun yang diperlukan. Ketika mengerjakan kampanye lain, dia terbukti mengembangkan strategi untuk 'menyusupkan berita' dengan menciptakan acara media yang mencari perhatian, menunjukkan cara yang dihitung media berita telah dikompromikan oleh kepentingan komersial.

Mengingat bagaimana film ini dimulai dan ditutup dengan René dan Guzmán akan melakukan bisnis seperti biasa, meskipun berada di pihak yang berlawanan selama kampanye, rasanya seperti Tidak membuat pernyataan suram dan suram tentang sifat dangkal dari peristiwa politik yang didorong media. Namun, fakta bahwa hasilnya adalah yang diinginkan yang menyarankan suka atau tidak suka, mengurangi politik menjadi pemicu emosional adalah efektif dan dapat digunakan untuk kebaikan. Tetapi bagaimana itu pada akhirnya melayani demokrasi? Apakah memenangkan No vote terhadap Pinochet layak dikompromikan yang dalam jangka panjang sangat merugikan demokrasi? Larraín dengan sengaja menghindari opini atau pernyataan konklusif. Di satu sisi sulit untuk tidak merasa sinis oleh adegan-adegan terakhir film atau oleh René yang pada awalnya mengkhawatirkan mobilnya dalam sebuah adegan di mana tidak ada demonstrasi yang dipatahkan oleh polisi. Motivasi René untuk mengambil kampanye 
adalah untuk tantangan profesional, dan kemungkinan prestise. Dia tampak lebih kesal dan tidak tenang ketika menyaksikan kekerasan atau mengalami pelecehan, bukannya marah. Dan Larraín masih menggambarkannya sebagai karakter simpatik yang dengan enggan berpisah dari istrinya yang radikal dan aktif secara politik dan berusaha membesarkan seorang putra.

Bahkan melalui pertempuran dimenangkan residu dari sistem tetap. Dan itu adalah sistem yang didasarkan pada kecerdasan dan ilusi: ilusi kesetaraan dan kepercayaan buatan dari ekonomi yang kuat ketika $40 \%$ penduduk hidup di bawah garis kemiskinan. Kemakmuran Chili sama khayalnya seperti kampanye branding minuman ringan, foto-foto bintang-bintang opera sabun yang dianggap glamor, atau film yang berpura-pura akurat secara historis tanpa mengakui keterbatasan dan manipulasi peristiwa sebenarnya untuk tujuan sinematik. Tidak ada satu pun dari hal-hal ini karena secara langsung ditujukan pada kepalsuannya sendiri dan protagonisnya serta kampanye buatan rekan sejatinya yang sebenarnya untuk mengakhiri kediktatoran yang menipu dan kejam. René mungkin dibiarkan terlihat kelelahan dan kecewa sementara sekali lagi mengatakan dialog yang sama yang dia gunakan dalam pitches, tetapi percakapan tentang bagaimana politik dikemas dan disajikan jauh melampaui batas-batas film, membuat No pemeriksaan yang sangat perseptif dan menarik dari efek yang dipicu media dan berputar pada proses politik.

Kemudian kekurang dari film ini adalah media yang digunakan tidak terlalu untuk mempromosikan kampanye politiknya dengan hanya memanfaatkan televisi yang ada. Dan saya rasa banyaknya pemain dari film ini malah membuat film ini terkesan amburadul.

\section{Noviyanti Azis (M6)}

"No" sebuah film yang rilis di 2012 berdasarkan latar belakang politik yang terjadi di era 1988, dimana saat itu mulainya dunia desain grafis menjadi salah satu kekuatan baru dalam memperoleh kekuasaan, menoreh simpati dan sebagai media komunikasi serta pemberi pesan dalam bentuk digitalisasi yaitu iklan.

Disutradarai oleh Pablo Larrain, Antonio Skarmeta sang penulis menggambarkan kerja keras, kreativitas para pemuda Chile di masa sulit dibawah kediktatoran pemerintahan Agusto Pinochet. Pada saat itu politik yang dibawahi oleh 
militer memberi luka pada masyarakat Chile. Terjadi banyak penyiksaan, pembunuhan dan penghilangan bagi yang menentang pemerintahan Agusto Pinochet, sehingga kelompok aktivis yang bersimpati terhadap nasibnya dan nasib masyarakat Chile pada umumnya membentuk kelompok untuk mengakhiri pemerintahan tersebut.

Latar belakang tersebut membuat terbentuknya referendum yang menawarkan dua kubu yaitu "NO" dan "SI". "SI" atau Yes menyatakan Agusto Pinochet dan kekuasaan militernya melanjutkan pemerintahan hingga 8 tahun lagi tentunya di prakarsai oleh tim Agusto Pinochet sedang "NO" menyatakan penolakan terhadap segala bentuk pemerintahan Agusto Pinochet dan memberikan waktu setahun untuk menyelesaikan masa pemerintahannya, Tim ini di prakarsai oleh Aktivis.

Jose Tomas Urrutia (kubu "No") yang berfikir bahwa kemenangan kampanye berpotensi baik apabila di tangani oleh ahli komunikasi politik kemudian memanfaatkan wadah iklan sebagai media untuk meruntuhkan tirani kekejaman pemerintahan Agusto Pinochet dengan mengajak seorang ahli desain grafis yang bekerja di bidang periklanan bernama Rene Saavendra. Rene Saavendra yang memiliki kehidupan yang damai bersama putranya berfikir tentang tawaran tersebut terlebih Rene Saavendra tahu tentang kubu lainnya (Si atau Yes) yang begitu didukung oleh pemilik perusahaan iklan tempatnya bekerja bernama Luis Guzman (Lucho), setelah melakukan diskusi dan pertemuan Rene Saavendra kemudian menerima tawaran tersebut. Tidak dijelaskan mengapa Rene Saavendra kemudian menerima tawaran tersebut, entah karena simpati dengan nasib warga Chile yang mendapat siksaan atau karena latar belakangnya yang memiliki seorang ayah yang meninggal karena kekejaman pemerintahan Agusto Pinochet atau karena Veronica, Istrinya yang tinggal terpisah darinya yang memiliki jiwa aktivis tinggi yang berusaha menentang kejayaan pemerintahan Agusto Pinochet meskipun sebelumnya dijawabnya bahwa Rene Saavendra hanya ingin kemenangan.

Keoptimisan Rene Saavendra dalam membawa konsep kebahagiaan membuat beberapa orang dalam kelompok tersebut pesimis dan keluar dari kelompok tersebut. Ada dua alasan yang membuat mereka keluar pertama mereka menyadari kekalahan tersebut diawal pertemuaan. Kedua, mereka kecewa dengan konsep iklan yang Rene Saavendra dan tim produksinya tawarkan sebagai iklan kampanye "NO" yang begitu cerah, penuh kegembiraan dan optimistic seakan menginjak-injak luka anggotalainnyakarena orang-orang yang bergabungdalam kelompok tersebut memiliki 
latar belakang keluarga yang hilang atau meninggal karena kekejaman pemerintahan Agusto Pinochet, iklan tersebut bagi mereka seakan sebuah penipuan.

Namun, Rene Saavendra melanjutkannya tanpa memperdulikan tanggapan tersebut meskipun beberapa kali mendapatkan kebuntuan ide, mendapat ancaman dari kubu lainnya (SI) seperti di ancam keselamatan dirinya dan keluarganya, hasil kerja mereka yang disabotase bahkan menerima pengasingan. Namun pada akhirnya kemenangan menjadi milik mereka. Kubu "NO" dengan tema Kebahagian yang serta merta mengakhiri pemerintahan Agusto Pinochet.

Film ini menggambarkan bagaimana pesimisnya pemikiran manusia dalam presentasi angka dan bagaimana optimisnya pemikiran manusia, yang jika mendapat dukungan dari orang-orang yang memahami dan mempercayai kemudian bersama-sama membangun pemikiran tersebut maka presentasi perhitungan logika dari kepesimisan akan berubah sangat drastis, bagaimanapun tangan-tangan tidak terlihat tersebut mencoba untuk menggagalkannya. Konsep yang ditawarkan oleh Rene Saavendra dan Tim produksinya sangat menarik dan tidak akan berani ditawarkan orang lain jika tujuan utamanya adalah kampanye politik dan juga sangat berbeda dengan konsep periklanan saat ini.

Konsep periklanan saat ini, dibandingkan memilih yang menarik mereka lebih memilih untuk menjadikan perasaan sebagai produk utama untuk menyakinkan seseorang, hampir sama dengan cara pandang masa lalu (model iklan kubu "SI" dan model iklan "NO" di pertemuan pertama Rene Saavendra) memperlihatkan kelemahan lawan, mengejeknya dan memakinya kemudian menawarkan diri untuk menjadi lebih baik. Hal tersebut juga menggambarkan, bagaimanapun canggihnya sebuah teknologi, peradaban pemikiran manusia hanya berorientasi ke masa lalu yang di modernkan sehingga tampak baru dan original.

Nilai yang terlihat menyakinkan para penonton bahwa media digital akan sangat mempengaruhi pengambilan keputusan negara dan internasional di masa ini dan masa depan. Negara butuh masyarakat yang kreatif, bermental kuat dan percaya diri tinggi, serta ditopang dengan orang-orang yang mampu mengerti dan memahami setiap perilaku negara dari kebijakan dan masyarakat didalamnya karena kolaborasi hal tersebut akan menciptakan berbagai hal di luar dugaan seperti yang terjadi dalam film "No" yang mampu menggulingkan kekuasaan "Si". 